\title{
Opening New Ways for Concepts to Cultivate Talents at Colleges while Returning Back to Old Traditions
}

\author{
Lin Lin and Lu Gao*
}

Keywords: My view on university; Concept of talent cultivation; Applicable talents; Talent training mode; Personnel training system

\begin{abstract}
Main function of the university is to cultivate talents, how the proposed and the needs of economic and social development to adapt to the talent training mode is the ultimate goal of each university to explore, the my university ", the author of a Book of Bohai University President by, book a comprehensive explanation of how to establish modern university system, built to adapt to social development needs of the new mode of development of the University, in today's society University School way has an important guiding significance.
\end{abstract}

\section{Returning Back to Old Traditions: Reshaping Emphasizing the Value of Cultivating Talents at Colleges}

Training talents is one of the major functions of colleges. Ever since the Medieval Times, when colleges first appeared, colleges have been shouldering the responsibilities of cultivating talents, which is the most basic task of colleges. Newman regards cultivating excellent talents as the fundamental task of colleges, believing that "the goal of colleges is to spread and promote knowledge instead of expanding knowledge". [1] Training talents is one of the inherent core functions of higher education ever since colleges first appeared and colleges are always paying attention to what kind of talents to be trained and how to train talents. The quality of cultivated talents will directly affect the reputation and competitiveness of a college. However, with the development of higher education, Humboldt's reform towards the University of Berlin and the proposition of "Wisconsin spirit", more attention has been paid to colleges' scientific research and social serving function, and various colleges pay less attention to their function of cultivating talents For example, Brubaker has a famous claim: "there are two main philosophies of higher education: one is based on epistemology and another is based on politics." [2] It has excluded the issue of cultivating talents from the philosophy of higher education. However, the three major basic functions of colleges cannot be isolated from each other because scientific research at college must be completed by someone at college and teachers and students at colleges also need to serve the society. Therefore, without cultivating talents, scientific research and social service function of colleges will become a castle in the air, which can be difficultly implemented.

With the development of economy and the society, colleges in China have gone through different stages of development in terms of cultivating talents: to cultivate talents with rich knowledge, to cultivate talents with professional skills and to cultivate talents with strong capacity. Talents cultivated under these goals played important role within certain period of time, but have also caused many problems. For example, in order to cultivate talents with rich knowledge, there will be bookworms who can only read books and get high scores in exams; and in order to cultivate talents with professional skills, there will be students with narrow horizon and limited comprehensive knowledge. In today's society, with the rapid development of information and technology, talents should not only firmly master knowledge, but more importantly, improve their comprehensive capacity and quality. Meanwhile, social development promotes humans to progress and humans' personal demands are gradually reflected. To a great extent, the problems in current talent cultivation at colleges are caused by that more attention is paid to conducting scientific researches and serving the society than cultivating talents with the lack of rational reflection of what talents should be cultivated and how to train talents in the new era. Therefore, under the background of new era, in order to achieve further progress, higher education should return to pay attention to cultivating talents and rethink what talents should be cultivated at colleges. 
There is an interdependent relationship of education and economy, either party will have significant causal influence on the behavior of the other." [3]In the book "My Outlook on Colleges", Professor Yang Yandong gives creative answers to problems in reforming the talent cultivation mode, which are worth learning by other colleges and universities. This book, which contains issues about the goal, mechanism and system of cultivating talents in the talent cultivation mode, not only gives answer to the goal of cultivating talents at colleges at the macro level, but also introduces the mechanism of cultivating talents at colleges fat the medium level as well as elaborates on specific practices in college teaching and management system at the micro level, so it can be said that Professor Yang Yandong is indeed well-intentioned. The author of this book is not only a higher education theory researcher, but also a practitioner with years of experience of managing higher education. He combines higher education theory and his decades of experience of managing higher education to discuss relevant issues in current higher education reform from the perspective of a college principal with clear attitudes and distinctive point of view, so this book is a rare masterpiece of books of this kind.

\section{Opening New Ways: Proposition of the Applicable Talent Concept}

It is undeniable that recalling people's attention on cultivating talents in colleges has great significance to the development of the society and higher education itself. The crux of the problem is that China is currently at the period of social transformation with knowledge constantly increasing and updating while the cycle is obviously shortened. The knowledge students learnt at school may become obsolete when they graduate from school. Emerging technologies like big data and cloud computing, especially the MOOCs have profoundly changed the teaching mode and method and are constantly reshaping people's understanding of education. Therefore, in the next decades, great changes may take place in the entire education field, and liberation of personality promotes human demands to become more personalized and diversified. Consequently, only mastering some certain knowledge and skills makes it difficult for people to follow up the pace of changing personal demands. Under such background, it is obviously for colleges to adapt to the demands of the time by cultivating talents with traditional concepts. The key problem for colleges to cultivate talents in the new era is to "pave new ways" in the concept of cultivating talents and establish new concept of talents.

Only by adhering to the concept of advancing with the times and constantly improving personal comprehensive qualities can we cope with the ever changing environment and satisfy our diversified demands. These comprehensive capacities include learning capacity, practical ability, and innovation capacity, etc. Learning capacity not only refers to basic skills of reading and writing, but also means that individuals should have the concept of life-long learning and constantly keep learning. Practical ability refers to that individuals can apply theories into practice to solve practical problems with strong practical ability. Innovation ability refers to that individuals have rich imagination and creativity instead of rigidly adhering to the old modes. Besides, individuals should also bravely propose new opinions or develop new technology.

Some universities in China have realized the urgency of cultivating students' learning ability, practical ability and innovative ability, and began to take measures to cultivate students' comprehensive ability. Cultivation of "knowledge" or "practical" talents by some schools as a general goal. "Knowledge" talent training objectives focus on imparting theoretical knowledge, so that students in learning to open the mind, gain insight, and ultimately cultivate the students' learning ability. Practical talents training objectives to pay attention to the practice, focus on cultivating the practical talents, change the students "Busy themselves in the classics and ignore what is going on beyond their immediate surroundings" situation and improve the students' practical ability. However, these two kinds of targets are obviously insufficient. Knowledge goals in focusing on teaching students' knowledge and lack of cultivation of students' practical ability, causing students to become "thought of the great action on the dwarf." [4] However, practice oriented goal in the importance of students' practical ability training while ignoring the importance of knowledge teaching, leading to the students' knowledge base is not solid, but ultimately affect the practical 
ability to play. In that case, we should combine the talents training goal of "knowledge" and "practical" essence, combine their advantages, reset the talents training goal. In fact, "My Outlook on Colleges" which was written by Professor Yang Yandong helps us to answer this question. It proposes personnel training goal, makes up the "knowledge" and "practical" personnel training objectives. The target of "application" is to emphasize the practice on the basis of mastering knowledge, and constantly innovate. The trinity of advocating moral, theoretical knowledge and practical ability. It not only cultivates students' learning ability and practical ability, but also emphasizes the cultivation of students' creative ability. The goal of "application type" is a more comprehensive description of the goal of talents training, not only to see the basic of theoretical knowledge, but also to realize the application of practical operation, and the development of thinking creation.

\section{Where to Go: In-depth Analysis of Talent Cultivation Mode}

Talent cultivation mechanism refers to the process of guiding and controlling the cultivation of talents with ideology, system and regulations, and making it operate efficiently. "Talent cultivation mechanism is mainly reflected in the management mode of cultivating talents, which mainly incudes the guiding ideology, setting of management organs, formulating of management documents and implementation of management work, etc." [5] The process for colleges to cultivate talents is not arbitrary, but to set specific operation rules according to the goals of cultivating talents to form certain management mechanism.

It has always been one of the issues troubling colleges as in which way to cultivate students can satisfy the demands of the society and individuals. Formulating unified standards can no longer satisfy the society's demands for diversified talents, nor those students whose personality has been liberated. Many colleges adopt the "one size fits all" concept to cultivate talents, so they can only cultivate talents of the same specification without their personal characteristics. This, on one hand, makes it difficult to give full play to the strengths and potential of students; on the other hand, it also causes the uneven distribution of talents with surplus talents of some majors and scarce talents of some other majors. After all, these problems are caused by problems in the talent cultivation mechanism. No talent cultivation mechanism in line with the demands of the time, society and individuals has been formed in colleges, thus there are various problems in talent culvtivation.

"In higher education, taking customers as the Center is difficult, as far as academic institutions, not strictly identify appropriate consumer [6]." Faced with such a serious problem, colleges and universities begin to reflect on talent training, and constantly explore, need to find a reasonable mechanism for talent training. In the overall concept, the diversion of training becomes the choice of some universities. Diversion cultivation is according to the needs of society and students with different interests and potential of the culture, in the process of the cultivation of students' advocate in accordance with different talent training specifications of students were cultured and maximize the play to their potential. Professor Yang Yandong in this book profound and detailed describes the triage training mechanism, and to the leadership of Bohai University as a case, specifically introduced triage training principle, the mode of education, the characteristics of problem, help researchers and managers' in-depth analysis of the shunt training mode, which is of great reference value to the reform of colleges and universities. In students' learning management, complete credit system has been adopted by many universities. "So-called complete credit system, is for course credit management and teaching, by the students themselves choose courses and classroom teachers, arrange their own learning process, making our own decisions about graduation time, in a certain period after Hugh prescribed course credits and cumulative reach graduation requirements to obtain the graduation certificate of teaching and school management system. "[7] In this book, Professor Yang Yandong profoundly analyzed the contents and characteristics of the credit system, requirements and security, to provide reference for our understanding of the credit system. In the daily management of the students, democratic management is increasingly valued by the university. Some scholars believe that the university is an academic community, I quite agree with the author. This academic community needs everyone to participate in the management, in order to mobilize 
the enthusiasm of the parties. For students, they should not just listen to the various arrangements of the numb, and should be active in the management process, to express their aspirations of the living person. In this book, Professor Yang Yandong put forward the students' self-management "three three system", that is, the student cadre appointment system, student cadre regular rotation system and student democratic participation system, the idea that students become the main body of management. Just as what is said in the book, "the student management is not for management and administration, its highest goal is not management, achieve self-management of students." Provide a useful reference for the management mechanism for the management of College students.

Talent cultivation system mainly involves the teaching and setting of course system in colleges. How to design teaching and arrange course system will directly affect the results of talent cultivation. It is hard for teaching modes that only emphasizes passing knowledge to cultivate students with strong practical ability, and also it is hard for course system that only contains courses of this major to cultivate versatile talents. In terms of the design of teaching and course system, colleges must clarify the purpose of cultivation and design a series of specific measures according to such purpose, and finally take actions and put into practice.

"Through coordination, standard University organization's internal and external relations, to ensure the University's cultural position, thereby enabling the University to better fulfil its responsibility for cultural heritage and cultural creativity." [8] At present, teaching and course design at colleges emphasizes more on teaching theoretical knowledge, which needs students to mechanically memorize knowledge without practice nor discussion with teachers. Consequently, students only memorize the knowledge points in learning and exams. How can college students cultivated under such mode to adapt to the demands of the society and market? No wonder it is ridiculed that graduation from college means finding no jobs. Faced with such situation, college students must awake and realize the importance of teaching and course setting. In order to cultivate students who can not only achieve high scores, but have strong practical ability, both learning theoretical knowledge and cultivating practical ability should be emphasized in teaching and course design. Yang Yandong professor in his book "My Outlook on College", Bohai university, for example, follows the elaborating management thought, detailed, concretely introduces the arrangement of classroom teaching design. He advocated the construction of the students' practical ability training as the center of the classroom teaching. This kind of lesson is divided into three levels: first, it is clear about what theoretical knowledge is; secondly, the students understand the usefulness of knowledge; finally let the students practice. This mode of lesson teaching students to learn knowledge, understanding of knowledge, the use of knowledge in the process of concentration in each class, help and urge students to learn. In addition, this book has made clear the students' ability of professional major problems, causes the student to study target, each show its long; originally introduced the content of the assessment system, saturated with the author the elaborating management thoughts. The author starting from the details and the Enlightenment of the child is father of the man, University administrators. [4]

"Universities are supposed to cultivate principled, respected leader; should train students to important values, character, morals, so they are willing to study for the well-being of the peoples of the world."[9] Of course, "My Outlook on Colleges" is by no means flawless. The author only discusses problems in talent cultivation of colleges but not discusses scientific research and social service. And the responsibility of colleges is not just to cultivate talents, but they shoulder the responsibility of developing science and serving the society. However, defects cannot belittle virtues. This book's exploration into talent cultivation mode has provided beneficial references for today's colleges in talent cultivation.

\section{Acknowledgements}

2014 general project of national social science "research into theories of ecological treatment of China's higher education during the period of one-way competition"(14BGL105), Educational Sciences of Liaoning province "Twelve-Five" planning 2015 project "study on academic influence 
of educational research institutions in Liaoning province" (JG15DB034), stage one. Educational science planning projects in Liaoning province "where the new barriers and solutions of talent training in colleges and universities (JG13DB174) Educational science planning projects in Liaoning province Analysis and Countermeasures of the phenomenon of "vulgar" in college students' life world"( L13CZZ044) 2014 Bohai University teaching reform project of a class project "qualifications for teachers' test 'background to strengthen the training of normal students' professional ability on the path "(BDJG-14-QN-A-003)

\section{References}

[1] [U.S] John•S•Brubaker. Higher Education Philosophy [M]. Translated by Wang Chengxv, etc. Hangzhou: Zhejiang Education Press, 2002, 13.

[2] [British] Newman. Dreams of Colleges [M]. Translated by Xu Xiaozhou. Zhejiang Education Press, 2001, 1.

[3] Xiao Ming. Comparative Analysis of Total Quality Management and ISO9000 Quality Management [J]. Theories and Practice of System Engineering, 1995(2): 63-68.

[4] Yang Yandong. My Outlook on Colleges[M]. Liaoning Education Electronic Audio and Video Publishing Press, 2014,58.

[5] Liu Ying, Gao Guangjin. Reform and Strategies of Talent Cultivation Modes of Colleges [J]. Heilongjiang Higher Education Research, 2011, (1).

[6] Sitalakshmi Venkatraman. A Frame-work for Implementing TQM in Higher Education Programs[J].Quality Assurance in Education,2007(1):99-112.

[7] Xiao Jurong. Reflection on Implementing Credit System at Colleges and Strategies for Reconstruction [J]. Modern College Education, 2001, (2).

[8] Zhang Yingqiang, Gao Guijuan. On the Cultural Orientation of Modern University System Construction [J]. Research of Higher Education, 2002(6): 28-331.

[9] [U.S.] Hari •Lewis. Excellence without Soul: How Harvard Forgets its Educational Aims [M]. Translated by Hou Dingkai, etc. Shanghai: East China Normal University Press, 2012:05. 